\title{
Populerization of maize among the small farmers of Ernakulam district of Kerala through front line demonstration
}

\author{
Vijendra Kumar Meena*, Shinoj Subramannian, Pushraj Anjelo and Dipti N.V. \\ Krishi Vigyan Kendra, \\ ICAR- Central Marine Fisheries Research Institute, Narakkal-682 505, India. \\ Received: 20-06-2015 \\ Accepted: 04-08-2015
}

DOI: 10.18805/ijare.v49i6.6686

\section{ABSTRACT}

To popularise maize crop (Zea maize) among small farmers of Ernakulam district of Kerala, Krishi Vigyan Kendra, ICARCentral Marine Fisheries Research Institute organised 25 demonstrations during 2012-13 to 2014-15 on traditional farmer's field. Maize cultivars Pratap-4 and Pratap-5 were used for demonstration during January to May and September to December season. Farmers were motivated and trained for maize seed multiplication and cultivation aspects. Results of demonstration revealed that Pratap-4, Pratap-5 and local variety produced 33.70, 30.7 and 23.4 q/ha, respectively. Average income generated by the crop range from Rs. 40440/- to Rs. 36840/- and local variety Rs. 30240/-. Cost benefit ratio was 2.18, 1.99 and 1.77. for Pratap-4, Pratp-5 and local variety, respectively. Technology index was reduced in the 2nd and 3rd year showed the feasibility of maize crop in the area. Thereafter, 500 farmers initiated the small scale farming of maize in the ণั district with the technical guidance provided from KVK.

Key words: Demonstration, Maize.

\section{INTRODUCTION}

crop, which can be grown in diverse seasons, ecologies and

it is used in industry and feed for animal and poultry. It is

known queen of cereal due to unparallel productivity among

cereal crops. Globally, it is cultivated on more than $160 \mathrm{~m}$ ha

area across 166 countries having wider diversity of soil

climate biodiversity and management practices.

In India, maize occupies third position both in area and production followed by rice and wheat (Anonymous, 2011). At present it is being cultivated on $8.6 \mathrm{~m}$ ha with the production of 21.7 million tonnes with an average productivity of $24.35 \mathrm{t} / \mathrm{ha}$. The productivity of India is just half than the world productivity. Lack of awareness about the multifarious uses of maize and availability of production technology viz suitable high yielding verities as well as poor knowledge about production practices are ascribed as main reason for low popularity and productivity of maize in Kerala. The productivity of maize per unit area could be increased by adopting recommended scientific and sustainable management production practices using suitable high yielding varieties through demonstration. Frontline demonstration is the new concept of field demonstrated evolved by the Indian Council of Agriculture Research ( ICAR) with main objective of demonstrate newly released crop production technologies and its management practices in the farmer, under different agro-climatic region of the country under the farming situations. While demonstrating the technologies in the farmer's field the scientist are required to study the factors contributing higher crop production. Field constraint of production and thereby generate production data and farmers feedback information. Taking into account the consideration s, frontline demonstration ( FLD ,s ) were carried out in a systematic manner on farmer, field to show the worth of a new variety and convincing farmer to adopt improved production management practices of maize for enhancing productivity of maize (Zea mays L.)

\section{MATERIALS AND METHODS}

The demonstration were conducted in 25 farmers field by the Krishi Vigyan Kendra, to know the production and economic benefits of scientific maize production technology technology in Ernakulum district of south zone VIII a of Kerala state during month of January to May and September to December season of 2012-13 and 2014-15 (three consecutive Year) in the farmer field in different village viz Mooknoor, Angamali and Prembhuoor panchyat. During these three year of study, an area 5 ha was covered, each farmer with 50 cent area $(0.5$ Acre $)$ under front line demonstration with active participation of farmers in selected village panchayat were conduct. Before conducting FLDs, the group meeting and skill training was imparted to the selected farmers regarding different aspect of maize cultivation. To popularize the scientific maize production technology, constrains in maize production were identified though participatory approach preferential ranking technique was utilized to identify the constraints faced by the responded to participating farmers in maize cultivation. 
The package of practices included were improved varieties, seed treatment, maintenance of optimum plant stand, recommended fertilizer dose. The spacing followed was at $0.60 \mathrm{~m} \times 0.25 \mathrm{~m}$ sown with the seeds rate of $25 \mathrm{~kg} / \mathrm{ha}$. The all participating farmer were trained on all aspects of maize production system. To study the of front line demonstration out of 25 participating farmer, total of 100 farmer were selected as respondent through proportionate sampling. Production and economic data for FLDs and local practices were collected and analyzed. The extension gap, technology gap and technology index were calculated using the formula as suggested by Samui et al. (2000).

Extension gap $\left(\mathbf{q h a} \mathbf{a}^{1}\right)=$

Demonstration yield $\left(\mathrm{qha}^{1}{ }^{1}\right)-$ yield of local check $\left(\mathrm{qha} \mathrm{-}^{1}\right)$

Technology gap $\left(\right.$ qha $\left.^{1}\right)=$

Potential yield $\left(\mathrm{qha}^{-1}\right)$ - Demonstration yield (qha- $\left.{ }^{1}\right)$

Technology index $(\%)=$

Potential yield ( $\mathrm{qha}^{-1}$ )- Demonstration yield/ Potential yield x100

\section{RESULTS AND DISCUSSION}

Constraints in maize production: Farmer's field maize cultivation problems were documented in this study. Preferential ranking scientific techniques were utilized to identify the constraints faced by the respondent farmer in maize production. The ranking given by the different farmers are given in Table 1. A perusal of table indicates that lack of suitable high yielding variety (HYV) $(85.00 \%)$ was given the top most rank followed by low technical knowledge $(85.00 \%)$. Based on the ranks given by the respondent farmer for the different constraint revelled that lack of suitable HYV,

TABLE 1: Ranks given by farmers for different constraints $(\mathrm{n}=100)$

\begin{tabular}{lcc}
\hline Constraints & Percentage & ranks \\
\hline Lack of suitable HYV & 85.00 & I \\
Labour problem & 80.00 & III \\
Low soil fertility & 30.00 & VII \\
Marketing & 75.00 & IV \\
Low technical knowledge & 85.00 & II \\
Wild animals & 60.10 & V \\
Vagaries of weather & 50.57 & VI \\
( Delay onset of monsoon, & & \\
Early withdrawn of monsoon) & & \\
\hline
\end{tabular}

low technical knowledge and other constraint such low or erratic rainfall, labour cost high, post harvest management were found to reduce maize production. Among all the constraints, low soil fertility got least concerns. Other studies (Dhaka et al., 2010; Ranawat et al., 2011; Sreelakshmi et al., 2012;) have reported similar problem in maize production.

Performance of FLD: A comparison of productivity levels between demonstrated varieties and local crop variety is shown in Table 2. During the period under study it was observed the productivity of maize in Ernakulum district under improved production technologies ranged 18.50 to $21.00 \mathrm{q} /$ ha herewith 18.66 mean yield of $21.85 \mathrm{q} / \mathrm{ha}$ for the varieties Pratap-4 and Pratp-5 and local. Yield of the front line demonstration trial and potential yield of the different varieties of crop was compared to estimate the yield gaps which were further categorized into technology index. The technology gap show the gap in the demonstration yield over potential yield $(60 \mathrm{q} / \mathrm{ha})$. Technology index show the feasibility of the variety at the farmers field. The lower the value of technology index more is the feasibility. Reduced technology index over the years of technology demonstration was also observed by several workers at different agro climatic conditions in different crops (Sawardekar et al. 2003, Dhaka et al., 2010, Kumar, 2012, Kumar, 2013, Kumar, 2014a and Kumar, 2014b).

The extension gap showed in decreasing trend in both varieties 4.60 to 3.40 and 4.80 to 3.85 . The technology gap ranging between 34.72 to 31.4 and 36.5 to $33.75 \mathrm{q} / \mathrm{ha}$ during the study period emphasizes the need to educate the farmers through various mean for adoption of improved agricultural production technologies to reverse the trend. The trend of technology gap reflect the farmer corporation in carry out such demonstration with encouraging result subsequent year. The technology gap observed might be attributing to the dissimilarity in soil fertility status and whether condition. Mukharji (2003) have also opined that depending on identification and use of farming situation, specific intervention may have more implication in enhancing system productivity. Similar finding were also recording by Mitra et al. (2010) and Katare et al. (2011) The wider gap in technology index both the variety (ranging between 57.86

TABLE 2: Yield of maize as influenced by improved production technologies and high yielding varieties over local practices in farmer's field (2012-14)

\begin{tabular}{|c|c|c|c|c|c|c|c|c|c|c|c|}
\hline \multirow[t]{2}{*}{ Year } & \multirow[t]{2}{*}{ Variety } & \multirow{2}{*}{$\begin{array}{c}\text { Area } \\
\text { ha }\end{array}$} & \multirow{2}{*}{$\begin{array}{l}\text { Demo. } \\
\text { No. }\end{array}$} & \multirow{2}{*}{$\begin{array}{c}\text { Potential } \\
\text { Yield }\left(\mathrm{qha}^{-1}\right)\end{array}$} & \multicolumn{4}{|c|}{ Yield (q/ha) improved technology } & \multirow{2}{*}{$\begin{array}{l}\text { Extension } \\
\text { gap (q/ha) }\end{array}$} & \multirow{2}{*}{$\begin{array}{c}\text { Tech. } \\
\operatorname{gap}(q / h a)\end{array}$} & \multirow{2}{*}{$\begin{array}{c}\text { Tech. } \\
\text { Index }(\%)\end{array}$} \\
\hline & & & & & Max. & Min. & Av. & local & & & \\
\hline 2012 & Pratap-4 & 3 & 15 & 60.00 & 30.00 & 20.56 & 25.28 & 20.60 & 4.60 & 34.72 & 57.86 \\
\hline 2012 & Pratap-5 & 2 & 10 & 60.00 & 28.00 & 19.00 & 23.50 & 18.70 & 4.80 & 36.50 & 60.83 \\
\hline 2013 & Pratap-4 & 3 & 15 & 60.00 & 32.56 & 22.76 & 27.66 & 23.85 & 3.81 & 32.34 & 53.90 \\
\hline 2013 & Pratap-5 & 2 & 10 & 60.00 & 29.50 & 21.06 & 25.55 & 21.30 & 4.25 & 34.75 & 57.91 \\
\hline 2014 & Pratap-4 & 3 & 15 & 60.00 & 33.70 & 23.50 & 28.60 & 25.20 & 3.40 & 31.40 & 52.33 \\
\hline 2014 & Pratap-5 & 2 & 10 & 60.00 & 30.70 & 21.80 & 26.25 & 22.50 & 3.85 & 33.75 & 56.25 \\
\hline
\end{tabular}


TABLE 3: cost of cultivation $\left(\right.$ Rs.ha $\left.^{-1}\right)$, net returns $\left(\right.$ Rs.ha $\left.^{-1}\right)$ and Benefit: Cost ratio of maize as affected by improved production technology over local practise

\begin{tabular}{|c|c|c|c|c|c|c|c|c|c|c|c|}
\hline \multirow{2}{*}{$\begin{array}{l}\text { Year } \\
2012\end{array}$} & \multirow{2}{*}{$\begin{array}{c}\text { Variety } \\
\text { Pratap-4 }\end{array}$} & \multicolumn{2}{|c|}{$\begin{array}{l}\text { Total cost of cultivation } \\
\left(\mathrm{Rs}^{-h^{-1}}\right) \text { Improved } \\
\text { Localtechnology check }\end{array}$} & \multicolumn{2}{|c|}{$\begin{array}{l}\text { Gross return }\left(\text { Rs.ha }^{-1}\right) \\
\text { Improved Local } \\
\text { technology check }\end{array}$} & \multicolumn{2}{|c|}{$\begin{array}{l}\text { Net return }\left(\mathrm{Rs}^{-h a^{-1}}\right) \\
\text { Improved Local } \\
\text { technology check }\end{array}$} & \multicolumn{2}{|c|}{$\begin{array}{l}\text { Benefit :cost ratio } \\
\text { Improved Local } \\
\text { technology check }\end{array}$} & \multirow{2}{*}{ 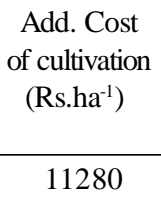 } & \multirow{2}{*}{$\begin{array}{c}\begin{array}{c}\text { Add. } \\
\text { Net } \\
\text { returns } \\
\left(\text { Rs.ha }^{-1}\right)\end{array} \\
8780\end{array}$} \\
\hline & & 17500 & 15000 & 36000 & 24720 & 18500 & 9720 & 2.05 & 1.64 & & \\
\hline 2012 & Pratap-5 & 17500 & 15000 & 33600 & 22440 & 16100 & 7440 & 1.92 & 1.49 & 11160 & 8660 \\
\hline 2013 & Pratap-4 & 18000 & 16500 & 39072 & 28620 & 21072 & 12120 & 2.17 & 1.73 & 10452 & 8952 \\
\hline 2013 & Pratap-5 & 18000 & 16500 & 35400 & 25560 & 17400 & 9060 & 1.92 & 1.54 & 9840 & 8340 \\
\hline 2014 & Pratap-4 & 18500 & 17000 & 40440 & 30240 & 21940 & 13240 & 2.18 & 1.77 & 10200 & 8700 \\
\hline \multirow[t]{2}{*}{2014} & Pratap-5 & 18500 & 17000 & 36840 & 27000 & 18340 & 10000 & 1.99 & 1.58 & 9840 & 8340 \\
\hline & Average & 18000 & 16166 & 36892 & 26430 & 18892 & 10263 & 2.04 & 1.62 & 10462 & 8628 \\
\hline
\end{tabular}

to 52.33 and 60.83 to 56.25 ) during the study period in certain region may be attributed to the difference in soil fertility status, weather condition, non availability of irrigation water and insect- pest attack in the crop (Singh et al. 1995).

The economic feasibility of improved technology over traditional farmers practices was calculated depending $\div$ on the prevailing prices of inputs and output cost (Table 3) it was found that cost of production of maize under improve

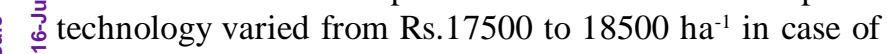
pratap 4, pratap 5 and local variety cost of production. Rs \% 15000 to 17000 in same years the addition cost incurred in o the improved technology was mainly due to more cost involved in the cost of improved seed only. Front line demonstration recorded higher means net return (Rs.18892 and 10263/ha) with higher benefit cost ratio both improved variety and local variety $(2.18,1.99$ and 1.77$)$ under it improved technology of different improved variety. improved production technology was perceptibly higher;

$\triangle$ there is urgent need to make stronger extension services for educating the cultivation in the implementation of improved maize production technology. However, the yield level under FLD was better than the local varieties and performance of these varieties could be further improved by adopting recommended production technology. Hence, it can be observed that increased yield was due to adoption of high yielding varieties and condition frontline demonstration of proven technology. Yield potential of crop can be increased to greater extent. This will subsequently increase the income as well as the livelihood of the farming community. From the above research finding it can be also conclude that the maximum number of the respondents had medium level of knowledge and extent of adoption regarding recommended maize production technology. The study reported lack of suitable HYV as major constraint by the beneficiaries and is ranked first followed by low technical knowledge.

\section{CONCLUSION}

On the basis of the results obtained in present study it can be concluded that new crops and technologies can be popularised in new area with front line demonstrations. Further this will help in reducing yield gaps (both extension and technology gaps).

\section{REFERENCES}

Anonymous (2011). Vision 2030. Directorate of Maize Research, Pusa, New Delhi(India).

Dhaka. B.L., Meena, B.S. and Suwalka, R.L. (2010). Popularization of improved maize production technology through frontline demonstration in south eastern Rajasthan. Journal of Agricultural Science 1:39-42.

Kumar, R. (2014 a). Crop technology demonstration: an effective communication approach for dissemination of wheat production technology. Agricultural Science Digest 34:131-134.

Kumar, R. (2014 b). Assessment of technology gap and productivity gain through Crop technology demonstration in chickpea. Indian J. Agric. Res.., 48:162-164.

Kumar, R. (2013). Evaluation of Crop technology demonstration of mustard crop in Transitional plain of Inland Drainage Zone of Rajasthan. International Journal of Agricultural and Statistical Sciences 9:657-660.

Kumar, R. (2012). Crop technology demonstration: An effective communication approach for dissemination of sustainable Green Gram production technology. Crop Improvement 39:1583-1584.

Narayanaswamy, C. and Eshwarappa. G. (1998). Impact of front line demonstration. Indian Journal of Extension Education. 34: 14-15.

Sawardekar, S.V., Dhane, S.S. and Jadhav, B.B. (2003) Front-line demonstration performance of salt tolerant rice variety in coastal saline soils. IRRN. 28:73-74. 
Singh, N. and Sharma F.L. (2004). Impact of front line demonstration on gain in knowledge about mustard production technology among farmers. In compendium of $2^{\text {nd }}$ National Extension Education Congress. May 22-24. 2004. Society of Extension Education. Agra \& MPUAT. Udaipur: 56.

Sreelakshmi, C.H., Sameer Kumar, C.V. and Shivani, D. (2012). Productivity enhancement of pigeon pea (Cajanus cajan L.) through improved production technology. Madras Agricultural Journal, 99:248-250.

Samui, S.K., Mitra, S., Roy D.K., Mandal A.K.and Saha D. (2000). Evaluation of Front line Demonstration on groundnut. J.Indian Soc. Coastal Agric. Res., 18:180-183

Singh. V., Singh R. P. and Pawar, K.S. (1995). Response of wheat (Triticum aestivum) to seed rate and date of Sowing. Indian Journal of Agronomy. 40:697-99.

Mukharji, N. (2003). Participatory Learning and Action. Concept Publishing Company, New Delhi, India. Pp. 63- 65.

Ranawat, Y., Ram H., Sisodiya, S.S. and Punjabi. N.K.(2011). Adoption of improved maize cultivation practices by trained and untrained farmers of KVK. Udaipur, Rajasthan Journal of Extension Education. 19: 144-147.

Katare, Subhas, S. K. Pandey and Mohd. Mustafa (2011). Yield gap analysis of rapessed- mustard through front line demonstration. Agric. Update. 6:5-7.

Mitra, Biplab and T. Samajdar ( 2010). Yield gap analysis of rapeseed- mustard through front line demonstration. Agric. Exten. Review, (April-June): 16-17. 